\title{
SOME ASPECTS OF IBAN-MALOH CONTACT IN WEST KALIMANTAN
}

\author{
Victor T. King
}

\section{Introduction}

The nineteenth century witnessed extensive Iban migrations from the upper Batang Lupar river ${ }^{l}$ in Sarawak's Second Division. The majority of Iban moved via the nearby Kapuas lakes and the Leboyan and Embaloh ${ }^{2}$ rivers of Dutch West Borneo (now West Kalimantan) and on to the Rejang basin the Third Division of Sarawak. However, much of the scholarly work which has been done on these important indigenous movements has focused on them in a Sarawak context. ${ }^{3}$ The main purpose of this study is to redress the balance by synthesizing and analyzing material on Iban migration and culture contact in Dutch territory. ${ }^{4}$ In the course of their spread into Dutch Borneo, Iban sometimes came into contact with other peoples already settled in these border regions (see Figure I). As Pringle says:

Beginning not long after 1800 the upper Batang Lupar Ibans began to migrate both into nearby areas of Dutch Borneo, and into the adjacent headwaters of the Katibas. These movements were mingled with

1. The Iban term for this river is the Batang $\mathrm{Ai}$, which simply means "the river." It is generally accepted that the main source of migration was from the upper Batang Lupar, also called the U1u Ai. In the Dutch literature Iban are usually called "Batang Loepars" since the Dutch thought that these people originated from that river in Sarawak.

2. The Embaloh river is known by the Iban as the Kanyau, and this term commonly appears in the Sarawak literature. However, the Dutch refer to it as the Embaloh (transcribed as "Embaloeh"). Other variations of the term are Támembaloh, Malo, Maloh, and Ambalau. This latter term is not to be confused with the Ambalau river further south in the Melawi drainage system.

3. See, for example, D. Freeman, Report on the Iban (London: The Athlone Press, 1970); B. Sandin, "The Westward Migration of the Sea Dayaks," Sarawak Museum Journal (SMJ), VII (1956), pp. 54-81; "Iban Movements from the Deluge (and the Survival of Dayang Racha)," SMJ, VIII (1957), pp. 117-32; and The Sea Dayaks of Borneo before White Rajah Rule (London: Macmillan, 1967); A. J. N. Richards, "The Migration of the Ibans and Their Poetry," SMJ, V (1949), pp. 77-86; S. Morgan, "Iban Aggressive Expansion: Some Background Factors," SMJ, XVI (1968), pp. 14185; R. Pringle, Rajahs and Rebels: The Ibans of Sarawak under Brooke Rule, 18411941 (London: MacMillan, 1970); U. Wagner, Colonialism and Iban Warfare (Stockholm: n.p., 1972).

4. Material for this article has been derived in large part from various published and unpublished Dutch sources supplemented with recent fieldwork data. Fieldwork was undertaken among Iban and Maloh people in West Kalimantan and Sarawak from August 1972 to September 1973, with the aid of grants from the Social Science Research Council, the Evans Fund (University of Cambridge) and the British Universities Student Travel Association, and archival research in Holland between August and September 1974 with the aid of a grant from The British Council. 


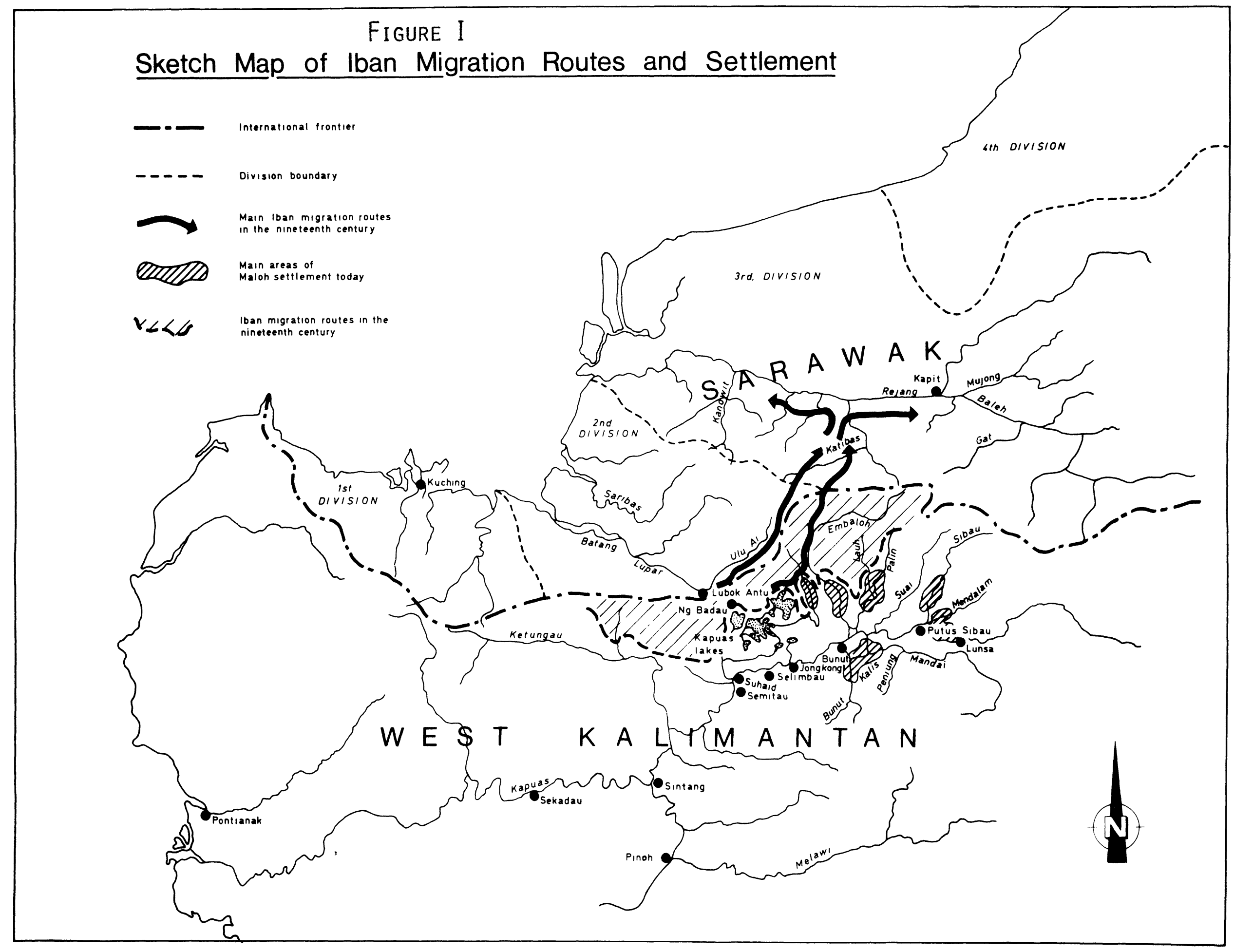


headhunting raids directed against the previous inhabitants of both regions: Bukitans, Ukits and other jungle nomads in the Rejang

drainage, Maloh Dayaks north and east of the lakes region, and Kantu Ibans in the region west of the lakes. ${ }^{5}$

But despite the association of migration with aggression and headhunting, it is apparent that Iban relations with other indigenous (Dayak) peoples was by no means solely characterized by hostility. For example, they established a symbiotic relationship with Bukitan nomads in Sarawak, ${ }^{6}$ and their contact with Maloh illustrates a range of relations from aggression and raiding to alliance, intermarriage, cultural exchange, trade and economic cooperation.

Anthropologists such as Andrew Vayda and U11a Wagner have studied the conditions and effects of Iban expansion and warfare from an ecological perspective. ${ }^{7}$ They suggest that these phenomena are closely related to such factors as pressure on land and vegetation, and competition for certain resources, particularly secondary forest areas. However, I have argued elsewhere that migration and warfare are complex processes involving not only ecological factors but also a multiplicity of socio-cultural variables. 8 Certainly Iban 1 and and vegetation resources were hard-pressed in their Batang Lupar homeland and the population needed to expand into new areas, but the acquisition of fresh heads and virgin forest in the course of this expansion were intimately associated with Iban values and beliefs concerning prestige, success, fertility and health. Furthermore, Iban were more interested in exploiting uninhabited tracts of virgin forest for swidden agriculture rather than in seizing secondary land already cleared and occupied by other peoples. ${ }^{9}$ In the nineteenth century there were vast areas of easily accessible virgin forest into which Iban could and did move without meeting much opposition from others. The conflicts which did occur were with small bands of nomads who had rights over tracts of virgin forest. Iban also came into contact with more powerful agricultural peoples such as the Maloh. Tensions and hostilities did arise over rights to virgin forest, but to a significant degree Iban also moved into an ecological niche left unoccupied by Maloh. The Maloh possessed areas of fertile alluvial lowland which could support a comparatively dense population by Bornean standards, whereas the Iban preferred to cultivate virgin forest. This complementarity provided the possibility of developing nonhostile relations.

Iban migrations were by no means continuous and unbroken. Initially, most of the regions to the north of the low-1ying Kapuas lakes were settled; Iban also founded villages along the upper courses of

5. Pringle, Rajahs and Rebels, p. 214.

6. Freeman, Report on the Iban, p. 134. See also my "A Note on Bukitan in West Kalimantan," Sarawak Gazette, CI (1975), pp. 2-3.

7. A. P. Vayda, "Expansion and Warfare among Swidden Agriculturalists," in A. P. Vayda (ed.), Environment and Cultural Behavior: Ecological Studies in Cultural Anthropology (New York: Natural History Press, 1969), pp. 202-220; "The Study of the Causes of War with Special Reference to Head-hunting Raids in Borneo," Ethnohistory, XVI (1969), pp. 211-24; Wagner, Colonialism and Iban Warfare.

8. V. T. King, "Migration, Warfare and Culture Contact in Borneo, A Critique of Ecological Analysis," Oceania (1976), forthcoming.

9. See Freeman, Report on the Iban, pp. 282-83, for a discussion of the advantages of farming virgin forest areas for the Iban. 
the Leboyan and Embaloh rivers. But there were significant, if sporadic movements backwards and forwards across the main watershed dividing British from Dutch territory. These were partly movements of individuals and families between kinsmen living on either side of the border. But they were also the result of inter-Dayak rivalries and feuding. In the nineteenth century the upriver Iban of the Batang Lupar were engaged in hostilities with downriver Iban and other Dayak peoples. Raiding Iban would take advantage of the political boundary between Sarawak and Dutch Borneo to engage in forays and then seek refuge on the other side of the border. Feuding between upriver and downriver Iban in Sarawak was also particularly exacerbated by the policies of the second White Rajah, Charles Brooke, who used coastal Iban as mercenaries in punitive expeditions against the supposedly more unruly Iban in remoter areas. It was the opinion of some Dutch writers, and this is borne out by the historical evidence, that these colonial actions played a part in increasing Iban tendencies to migrate and take heads. 10 Many upriver Iban moved not only to escape punishment meted out by the rajah's forces, but also to retain their independence, freedom of movement and traditional way of 1 ife. As this study will reveal, the intervention of the colonial powers, both British and Dutch, had important effects on migration, warfare and inter-Dayak relations.

Iban-Ma1oh Contrasts

This section is intended to provide an ethnographic back-drop for the later more detailed historical discussion. Certain social, economic and cultural differences between Iban and Maloh go some way to explaining the nature of Iban-Maloh contact.

First, it should be noted that despite many differences Iban and Maloh exhibit broad cultural similarities and individuals can pass from one Dayak culture to another with comparative ease. Although I present below various features of Iban and Maloh society, I do not claim that the boundaries of these respective units can be easily or unambiguously demarcated, nor am I dealing with features common to all Iban and Maloh. I am more specifically concerned with those Iban in West Kalimantan who are migrants and their descendants from the upper Batang Lupar. The following description can also be applied to those Iban of the Third Division of Sarawak studied by Freeman. The Maloh are more problematic. The Maloh who came into close contact with Iban are those of the Embaloh subdivision. 11 They are mainly found on the Leboyan, Embaloh, Lauh and Palin rivers and exhibit quite marked cultural differences from the other two Maloh subdivisions of Kalis and Taman located to the south and east of the Embaloh. My description of Maloh will therefore refer specifically to the Embaloh. In certain instances I will use the term "Embaloh" to indicate that my data has been derived only from that subdivision.

10. See, for example, H.A.A.N., "Batang-Loepars. - Verdelgingsoorlog. EuropeeschDajaksche Sneltocht," Tijdschrift voor Nederlandsch Indië, I (1887), pp. 33, 53.

11. See my "Additional Notes on the Malohs and Related Peoples of Kalimantan Barat: The Value of Dutch Ethnography," SMJ, XX (1972), pp. 83-105; "Maloh Social Structure," in J. Rousseau (ed.), The Peoples of Central Borneo (Kuching: Sarawak Museum; Special Issue, Sarawak Museum Journa1, 1974), pp. 203-27; "Cursing, Special Death and Spirits in Embaloh Society," Bijdragen tot de Taal-, Land-en Volkenkunde, forthcoming. 
First and foremost there is a considerable difference in language between Iban and Maloh. The Iban language, unlike Maloh, is very similar to the various Kapuas Malay dialects. Since Malay is the 1 ingua franca of West Kalimantan, Maloh have no difficulty in mastering Iban. In conversation with Iban the Maloh almost invariably use the Iban language interspersed with some upper Kapuas Malay variations. Iban people rarely speak Maloh.

In material culture there are also many contrasts. Long-house design varies appreciably. Painted motifs used for decorating shields, walls, canoes and ritual paraphernalia differ, as do designs on mats and baskets. Maloh are skilled in beadwork whereas Iban concentrate much more on the weaving of multi-colored short skirts, jackets and blankets. Iban tend to be more expert in decorative basketware and mats. On the other hand, up until recently Maloh men were widely known as metal craftsmen. A common Maloh product was the hooped corset made from copper or silver, usually worn by Iban women. This kind of specialization indicates that there was considerable trade between Iban and Maloh. Although both peoples have a rice cult, practice augury, and share a number of similarities in beliefs about the dead, sacred places and spirits, Iban and Maloh religious complexes as totalities are markedly different.

The most significant differences are found in the socio-economic sphere. In general, certain elements of Maloh socio-economic organization, as represented in the Fmbaloh subdivision in particular, give an impression of permanency. Embaloh people have been settled in their present location for a long period of time, extending back more than twenty generations. Their villages are situated in the flat land bordering the rivers, and their rice fields are mainly spread out on fertile flood-plains (tana" dasapui danum, "land flooded by water"). The quality of the soil allows Embaloh, who mainly practice dry rice swidden agriculture, to return to the same tract of land after a relatively short fallow period of about eight to ten years.12 While the good soil is thus one of the reasons for comparatively high local rice yields the Embaloh are also conscientious farmers. An important prerequisite for a good harvest is thorough weeding of rice plots, and this the Embaloh women undertake with painstaking care. The flat riverine terrain facilitates such weeding, while steep hill land makes it very onerous. Prior to sowing an area, men and women are careful to ensure that as much as possible of the cleared vegetation is burned over. 3 Larger trees are felled and their branches removed and collected together for burning. After the main burn any remaining unburnt or semi-burnt debris is placed in piles and reburned. Embaloh generally prefer to clear secondary rather than virgin forest since the latter requires amuch longer dry period before it will burn well. This is not to say that Embaloh do not farm hill land. Certain villages have a considerable amount of such land within their territories, and in the past Embaloh villages located further upstream relied much more on higher land for rice cultivation. Today, however, Embaloh generally concen-

12. There are dangers in farming low-lying areas. If floods occur at certain crucial times in the rice cycle, crops can be badly damaged. But the risks are lessened insofar as Embaloh settlement is generally located along the middle courses of rivers, and flooding is neither as extensive nor as long-enduring as it is further downriver toward the main Kapuas.

13. Maxandrea, De Dajaks in de Binnenlanden van Ned. Borneo (Grave: Missie der P. P. Capucijnen, 1924), p. 110 . 
trate their greatest efforts on low-1ying areas, and they are often greatly amused, sometimes even cynical, when they point to neighboring Iban farms perched precariously on steep hill slopes.

Embaloh villages also grow a relatively large percentage of swamp rice, which they sometimes cultivate for three to five years in succession on the same plot. More recently they have eagerly turned to wet rice agriculture using high-yielding seeds distributed by the government. But this activity is nowhere as sophisticated as in other lowland Southeast Asian wet rice systems, and in most cases merely amounts to the construction of simple drainage and irrigation channels.

The fertility of these riverine locations and Embaloh skills in farming frequently produce a rice surplus, which is then turned into various kinds of heirloom property, and, in recent years, such consumer goods as outboard motors and transistor radios. That the Embaloh region has been relatively wealthy for some time is illustrated in the Dutch literature. Enthoven, for example, says of the Leboyan and Embaloh:

Connected with the fertile farmlands to which the Leboyan people have rights, they are very wealthy; bad harvests and accompanying famine seldom occur. 14

The Embaloh people are generally recognized as wealthy: indeed they have good farmland, they are very industrious and were never subjected to the harassment of Malay rulers. 15

In contrast Iban in West Kalimantan very rarely farm low-1ying areas, and are usually situated further upriver along sidestreams where land is higher and more steeply sloping. This does not mean that Iban adhere rigidly to hill rice cultivation, or that they are generally, or were traditionally, inhabitants of remote interior upland regions. Nevertheless, as the majority of Iban occupy the large areas of forest-covered hilis in Sarawak and the border regions of West Kalimantan, Pringle concludes that:

it is the shifting cultivation of hill rice, preferably in areas of virgin jungle, which is fundamental to the Iban concept of the good life. The cycle of hill rice cultivation is marked at every stage by the rites of a padi cult which lies at the heart of Iban religion. 16

Where hill land is available, and more especially where there are large areas of virgin forest, Iban will opt for this rather than for lower-lying 1and. Apparently this is what they did in their migrations into West Kalimantan and beyond. In effect, they were not particularly interested in gaining access to Embaloh-settled regions, not only because they expected formidable resistance, but also because they were more attracted to the vast areas of unoccupied virgin hill land.

When farming virgin forest, the Iban usually cultivate half or more of a farm for two years in succession. Freeman points out that "it is not unusual. . . that land is cultivated three times in the

14. J. J. K. Enthoven, Bijdragen tot de Geographie van Borneo's Wester-Afdeeling (Leiden: Bril1, 1903), p. 60 .

15. Ibid., p. 63 .

16. Pringle, Rajahs and Rebe1s, p. 27. 
first five to seven years following the felling of virgin forest."17 On the other hand, in secondary growth areas it is usual to take only one crop and then allow the land to revert to secondary vegetation for sometimes as much as fifteen years.18

There are, of course, ecologically "justifiable" methods of swidden cultivation, but Freeman concludes that:

Of the fact that the methods employed by the Iban are prodigal of natural resources and frequently produce deleterious results there can be no doubt. Particularly to be condemned is their custom of cultivating land for two, or three years in succession, or several times within a span of five or six years. ${ }^{19}$

Many Dutch observers on the other side of the border also remarked on the wasteful practices of the Iban. ${ }^{20}$ The mission records in Benua Martinus mention that in October 1921 a number of Leboyan people were complaining about Iban who had established themselves there and depleted the land.21 Again in 1922 it was reported that Dutch officials were engaged in resettling Iban from exhausted farming areas. While it was felt that the upper Kapuas districts could absorb them the Dutch Catholic priests at Martinus thought it best to restrict Iban to their present areas since they spoiledland with their farming practices, and, after rendering it useless for future use, moved on to new regions.22 My own observations on Iban agriculture on the upper Embaloh and Le boyan lend weight to these general comments.

Thorough weeding is necessary for a successful harvest, and, as we have seen, the Embaloh were conscientious in this regard. Iban, however, are less so, and Freeman points out that:

At Rumah Nyala one or two farms were weeded with the greatest of care, while others were left either unfinished or only perfunctorily covered. 23

He draws attention to the difficulty of weeding when working in a steep terrain obstructed by logs and tree stumps, and comments that, like the

17. Freeman, Report on the Iban, p. 289.

18. Ibid., p. 160.

20. See, for example, Enthoven, Bijdragen tot de Geographie, p. 227; G. A. F. Molengraaff, Geologische Verkenningstochten in Centraal-Borneo (1893-94) (Leiden: Bri11, 1900), pp. 119-21. C. Kater, "Iets over de Batang Loepar Dajakhs in de 'Westerafdeeling van Borneo,"' De Indische Gids, V/1 (1883), p. 3, points out that the Iban are by no means idle in their farming but that they frequently do not plant enough rice, and consequently experience rice shortages. I suspect that it is much more a question of farming practices and quality of land that accounts for the Iban failure to harvest adequate rice.

21. These unpublished mission records, entitled Archief Statie Benua Martinus 19121946 , provide a wealth of data on the Embaloh river. They were mainly compiled by Pastor F. Hujbers, who was resident in the Embaloh for most of the period in which the Capuchin order was established there. In future, data from these records will be referred to by the abbreviation A.S. and a date of entry. I also retain the Dutch spelling of "Benua," although in the Embaloh language it is rendered "Banua."

22. Ibid., April 17, 1922.

23. Freeman, Report on the Iban, p. 193. 
Embaloh, the Iban did cut away the branches of larger trees to improve the chances of a good burn, but he also notes that:

Such a subsidiary cutting over of a farm is onerous work however, involving long hours of precarious scrambling among tangled and splintered branches, and very few men tackle the job with thoroughness. ${ }^{24}$

In Iban villages on the Embaloh it was apparent that the men were reluctant even to undertake the task of paring branches prior to burning, and, unlike the Embaloh, they did not reburn the accumulated debris left after the first burn. Embaloh people also point out that, in general, Iban farms, because they are less clean, are also larger in area than their own. Since the less fertile hill farms require a larger area to produce sufficient rice, weeding efforts have to be spread over a wider area, and in consequence tend to be less thorough.

Another important difference is that because Embaloh fields are typically fairly close to their areas of settlement and correspondingly distant from deep forest, the problems of pest control are minimized. On the other hand Iban frequently farm close to or in virgin forest, and the risk of damage to crops by wild pigs, monkeys and other pests is considerable.

Finally, young Iban males welcome the prestigious operations of clearing virgin forest and carrying in loaded baskets of harvest rice, but undertake "unmanly" jobs like weeding with reluctance and only if real need arises. Men usual1y go on their travels between the clearing and harvesting period. But Embaloh men appear to be less convinced of the positive male virtues of clearing and carrying and are more prepared to assist women in their tasks as well.

It seems then that the Iban prodigal use of resources and their less careful farming methods are partly related to the fact that, in the past, and to a certain extent today, there were always vast areas of unpopulated virgin forest into which they could easily move.

A further factor in Iban migration and indiscriminate resource exploitation may have been the dislocation of the Iban economy in certain areas. Iban were subject to sporadic punitive expeditions by the Brookes. Wagner suggests that a relatively small government force could render homeless and without food about 1,300 Iban. 25 For example, in the rajah's Kedang Expedition (1886) the whole country on both sides of the border was 1 aid waste and eighty villages were destroyed. About six to eight thousand people were probably left without food and. shelter. Government efforts were not so much directly towards inflicting casualties on the enemy as to looting and burning houses and food supplies, as wel1 as destroying fields and rice crops. Since Iban did not always harvest rice surpluses the destruction of a whole crop could mean scarcity of food for a few years afterwards. Furthermore, the looting meant that Iban could no longer exchange heirloom property for food. These deleterious effects on the Iban economy, although probably short-term, could also partly explain the Iban need to migrate, and their somewhat prodigal use of resources, since rice suppiies were required quickly to cover such severe losses.

24. Ibid., p. 177.

25. Wagner, Colonialism and Iban Warfare, pp. 58-59. 
Respective long-house types and settlement patterns in Iban and Maloh society are closely in tune with their different patterns of agriculture and mobility. Harrisson has already remarked on the permanent nature of Maloh houses.26 They were traditionally built on massive ironwood piles; sometimes their floors were as much as twenty-five feet above the ground. Heavy planks were also used for walls and parts of floors. The sheer labor invested in construction of this kind discouraged mobility. Houses were like fortresses surrounded by defenseworks of sharpened bamboo poles, man-traps and ditches. ${ }^{27}$

If the house was abandoned for any reason then a new dwelling was usually built nearby, and, in the past, if a long-house became overpopulated another house was erected in the vicinity. The nature of these houses and the settlement pattern were closely related to needs of defense, but fertile soils and frequent rice surpluses also permitted the Maloh people to cluster together. With the reduction in raiding and feuding, and because of various internal pressures and external government and missionary influence, gradually a number of large houses were abandoned in favor of smaller, less solid long-houses and individual family dwellings. Nevertheless, village locations still remain fairly permanent and Maloh prefer to stay close to their ancestral 1 ands.

In contrast the Iban long-house is usually a much more temporary structure. In the past Iban seldom kept the same house site for more than ten years. 28 Today their movements, although restricted by government, are still appreciable. Long-house support posts are smaller and building materials tend to be lighter than the Maloh's. The floor of the house is also fairly close to the ground. Houses are generally a greater distance apart and the population density low. In turn, this type of settlement pattern and house structure are related to Iban commitment to mobility, their prodigal cultivation methods and the lower fertility of hill areas which cannot support dense populations.

There is a marked difference between Iban and Maloh social organization. Maloh have a ranked social structure. In the past the headman of the village was always chosen from upper-ranking villages (samagat). By virtue of their aristocratic position, descent from powerful ancestral spirits, possession of various charms and ritual formulae, and role in village ritual, these headmen had a significant hold over lower-ranking (banua) and middle-ranking (pabiring) villagers. In addition, they could impose heavy fines on individuals or families who wished to move elsewhere without good reason. All this meant that the samagat could usually keep control over their subjects and restrict their mobility. Recently, however, with the spread of education and egalitarian ideals, the position of headman has been democratized. Now he is elected by all village members, and in consequence the samagat rank has declined in importance in village affairs. Still, in

26. T. Harrisson, "The Malohs of Kalimantan. Ethnological Notes," SMJ, XIII (1965), pp. 343-44.

27. Enthoven, Bijdragen tot de Geographie, p. 59. Today most of these traditional structures have disappeared, although some are still to be found along the Palin river.

28. J. E. L. Burgemeestre, "Memorie van Overgave van den Gezaghebber van Semitau," (unpublished Memorie van Overgave [Mv0], Tropen Instituut, Amsterdam, 1934), p. 7 . 
some areas, such as along the Palin river, samagat are still held in some respect and are consulted in matters of customary 1 aw.

In contrast to this, the position and powers of the Iban headman (tuai rumah) were and are much less significant. Freeman stresses the essentially democratic, egalitarian quality of Iban society, and the independence of individual families (bilek).29 This independence and the lack of a restrictive hierarchical authority are closely connected to the frequent movement of families between long-houses and the general tendency of Iban to migrate.

Maloh permanency seems also to be related to their land-tenure system. The first clearing of virgin forest establishes rights in land, and ideally these rights are passed down to all the pioneer's descendants. This means that every individual belongs to a number of property-based descent units (kapulungan). Rights embrace not only land but fruit trees, certain valuable jars and gongs, and long-house support posts. Shared rights in property result in a complex web of relationships which spread out and connect a large number of individuals in Maloh society. Even if a man moves from his natal village he still retains rights over property there, and some of his children may well return to their father's village and activate these rights. This system seems to be consonant with the close movement of people within a restricted area and the higher degree of permanency of Maloh settlement .

For the Iban, rights in 1 and and property are held independent $1 y$ by each bilek-family. Unlike the Maloh, when an Iban individual moves from his bilek to marry, and the marriage shows signs of lasting, he must relinquish his rights in the property of his natal family. There is very little inducement for him to return, unless perhaps in cases of divorce, since his rights are now located in the bilek of his spouse. Iban inheritance and ownership is fully in line with the independence and the greater mobility of Iban bilek-families.

Finally Maloh immobility and accessibility has, in part, resulted in a greater penetration of missionary and governmental influence. Dutch Catholic missionaries, for example, placed a mission station, church and school at Benua Martinus in the heart of Embaloh country, where they had access to a relatively large and permanent population. (In fact, the missionaries moved to the Embaloh after their lack of success further west in Iban country.) The introduction of missionaries also led to the growth of Dutch government agencies in the area. The missionaries among the Embaloh people also noted their greater degree of receptivity to the opportunities offered by education. 30 They seemed less resistant to outside influence, partly because they desired protection from Iban raids. Consequently some of their customs have almost disappeared. The Iban, however, living in the more remote upriver areas, were more difficult for the government to control and the missionaries to convert. They seemed to offer greater opposition to the overtures of outsiders, and showed a strong tendency to retain their customs. The Iban needed little from the Dutch and resented attempts to curb their traditional freedom and mobility.

29. Freeman, Report on the Iban, pp. 128-29.

30. P. Ignatius, "Een Wandeling naar de Embaloeh-Dajaks," Borneo-Almanak (1913), pp. 52-56. 
This general contrast between Maloh permanency and Iban expansion and migration is a somewhat ideal-typical sketch. In the distant past the Maloh as a whole were also migratory, moving inland from the coasts of West Kalimantan. But, unlike Iban, the main Maloh genealogies date from a time when the broad patterns of present-day Maloh settlement had already been established. Much of their mythology relates to the upper Kapuas, whereas Iban oral tradition is grounded in a context of migration. It appears after an initial expansion, Maloh settlement on the upper Kapuas suffered some contraction. Maloh oral tradition indicates that their villages were once spread along the main Kapuas river above Bunut, extending past the present village of Lunsa, and were also widely spread out along various tributary streams. But the Embaloh people have since become concentrated on the middle reaches of the Embaloh and Leboyan rivers, partly as a result of Iban movements into the area in the last one hundred and fifty years (see Figure III). Another subdivision of Maloh, the Taman, were also reduced in numbers and extent by their enemies the Kayan, who launched a devastating at tack against them in the nineteenth century. ${ }^{31}$ It is also likely that the reduction in numbers of Maloh along the main river was also the result of the gradual extension of Malay culture into the upper Kapuas. Some Maloh converted to Islam and "became Malay." Finally, since the latter part of the nineteenth century, areas previously long occupied by Maloh have been filled by Kantu peoples who were moved by the Dutch from border regions and the danger of Iban attacks.

On the other hand, not all Iban are characterized by mobility and a scattered settlement pattern. There are downriver Iban in Sarawak who live in fairly large and permanent long-houses and have an "incipient" ranked social structure.32 It is also rather misleading to see Iban as unduly aggressive and hostile, since other Dayak peoples such as the Kayan also exhibited aggressive tendencies, and in stories of Iban-Maloh raiding it was by no means Iban who had it all their own way.

What I have attempted to do in the above is to describe a constellation of features within two separate frameworks. In effect, these features can best be seen as constituting two rather different ecosystems: the Maloh (and more specifically the Embaloh), characterized by more permanent settlement, a more intensive and skilied agriculture, and a ranked social system; and the Iban, marked by more temporary settlement, a more extensive and prodigal agriculture, and an egalitarian social system. The tracing of cause and effect between environment, socio-economic organization, culture and extraneous factors is at best problematic. ${ }^{33}$ For present purposes it is enough to note that the features described are related one with the other in complex and. various ways.

\section{Early Iban-Maloh Contact}

When the Dutch arrived in the upper Kapuas Iban expansion and migration from Sarawak had already begun. The Dutch naturally assumed

31. M. A. Bouman, "Ethnografische Aanteekeningen omtrent de Gouvernementslanden in de Boven-Kapoeas, Westerafdeeling van Borneo," Tijdschrift voor Indische Taal-, Land- en Volkenkunde, LXIV/185 (1924), p. 182.

32. Pringle, Rajahs and Rebels, p. 36.

33. See, for example, Morgan, "Iban Aggressive Expansion," pp. 145-54. 
that the Batang Lupar was the Iban homeland. But Sandin's detailed record of Iban oral tradition indicates an origin not in Sarawak but in West Kalimantan. The migrations beginning in the $1800 \mathrm{~s}$ from the upper Batang Lupar were merely a late stage in a long history of Iban movements. Early Iban history is shrouded in myth and legend, but it appears that long ago people ancestral to the Iban lived in the coastal region of West Kalimantan south of Pontianak. For various reasons, one of which was the desire to avoid the thrust of Islam along the coast of West Borneo, these proto-Iban moved inland. The exact routes and nature of these early migrations are difficult to determine, but it seems that migrants came into contact with such middle Kapuas peoples as the Mualang and Bugau. From there some proto-Ibanic groups moved further upriver into the Selimbau and Jongkong regions, and then to the east of the Kapuas lakes, probably touching the Leboyan river. ${ }^{34}$ Eventually they crossed the watershed into Sarawak. Others entered Sarawak by routes farther west. Sandin's account suggests that these migrations from Kalimantan into Sarawak occurred some fifteen generations ago.

The genealogical material which I collected from the Embaloh suggests that people ancestral to the Maloh were already well-established along the upper Kapuas at least twenty generations ago, well before Iban began to enter the region. It is tempting to suggest that the existence of this early Maloh population, particularly along the northern tributaries to the east of the lakes, proved an obstacle to the eastward expansion of the Iban and forced them north and west into Sarawak. This, however, is largely conjecture, since neither Iban nor Maloh oral traditions provide any definitive evidence.

Harrisson tentatively suggests that the Iban may have been, in part, a western offshoot of Maloh from these early times, and that, in any case, there must have been some cultural interchange and merging. 35 This is a reasonable supposition, but the nature and effects of these early contacts are difficult to establish with any degree of certainty. Early mutual influences have probably been overshadowed and obscured as a result of the more recent Iban-Maloh contact dating from the nineteenth century. However, the differences which exist between present day Iban and Maloh would tend to suggest that they are not of common stock. Common origins seem more probable in the case of $I$ ban and the middle Kapuas peoples such as the Mualang, Bugau, Seberuang and Kantu, since these are all culturally very closely related. 36

\section{Other Pre-Dutch Contacts}

After this early period up until the nineteenth century there is very little evidence of significant contact between Iban and Maloh. Maloh say that the relatively infertile and swampy areas to the north of the Kapuas lakes were largely uninhabited before Iban migrations from Sarawak occurred some six to seven generations ago. In Sandin's

34. Ibid., pp. 158-60; also my "Main Outlines of Taman Oral Tradition," SMJ (1975), forthcoming.

35. Harrisson, "The Malohs of Kalimantan," pp. 243, 334.

36. See, for example, D. Dunselman, Kana Sera, Zang der Zwangerschap (Leiden: Nijhoff, 1955), p. 279; F. H. van Naerssen, "Een Streekonderzoek in WestBorneo," Indonesië, V (1951-52), pp. 145-56; V. T. King, "Kantus of the Kapuas River," Sarawak Gazette, IC (1973), pp. 254-57. 
extensive writings on Iban ethnohistory there is only one story relating to Maloh contact which involves a Maloh silversmith called Nyerubong. ${ }^{37}$ The incident took place some thirteen generations ago after the Iban had already migrated into Sarawak. Apparently Nyerubong $v$ is ited the house of the Sarawak Iban leader Radin. He stayed there for three years and on his return to the upper Kapuas met another Maloh, Apai Kejuang, who was leading a raiding party against Radin. Nyerubong joined forces with him, but they were defeated. From Embaloh oral tradition, I collected only two early stories of raids into Sarawak. Some eight generations ago Raja Dót, the headman of the former village of Malit on the upper Embaloh river scored a victory over some Second Division Iban. In addition, Renderan and his son Batinggal from UkitUkit on the Leboyan river also launched attacks on the Iban of the Batang Lupar. These incidents were characterized by smal1-scale, longdistance raiding for heads and did not seem to be related to competition for land resources.

In the past, however, Maloh were widely known for their silver-, copper, and gold-working skills. Itinerant Ma1oh smiths would often travel to Iban long-houses in Sarawak and remain for fairly long periods of time, making various adornments such as earrings, bracelets, belts and headdresses for the locals. (Today, Maloh metal-working skills have largely disappeared, mainly because of competition from imported and Chinese-made jewelry, and the decline in traditional customs and dress.) In return for Maloh articles, Iban would trade woven blankets, skirts and jackets. The possession of a skill meant that individual Maloh craftsmen were usually welcomed by Iban and were granted safe passage through their country. Sometimes they might even marry an Iban woman.

Perhaps it is the existence of Iban-Maloh trade which has led Harrisson to suggest that relations between them have sometimes been close and to a significant degree "free of large-scale and continuing hostility."38 But there has also been much mutual hostility and feud ing. ${ }^{9}$ Trading relations and ties of kinship and friendship were centered around wandering individual craftsmen. At the group and village level, however, relations seem to have been characterized by raiding and feuds, particularly in the course of the nineteenth century.

Iban Movement into Dutch Borneo

It is difficult to pinpoint the period when Iban first began to move into Dutch West Borneo and thus came into greater contact with Maloh. The main authorities agree that this movement began during the early decades of the nineteenth century. ${ }^{0}$ Just before and during this time Iban peoples were already raiding widely over the Kapuas area. They engaged in attacks on the petty Malay sultanates of Selimbau, Suhaid and Sekadau. Enthoven, for example, mentions Iban raids in 1823 against Abang Tella, the Malay ruler of Selimbau.4 Mualang, Kantu

37. Sandin, The Sea Dayaks of Borneo, pp. 30-31.

38. Harrisson, "The Malohs of Kalimantan," p. 247.

39. See, for example, King, "Additional Notes," p. 89.

40. See, for example, Freeman, Report on the Iban, p. 132, and Pringle, Rajahs and Rebels, pp. 213-14.

41. Enthoven, Bijdragen tot de Geographie, pp. 159-61. 


\section{FIgURE II \\ Sketch Map of the Embaloh \& Leboyan Rivers}

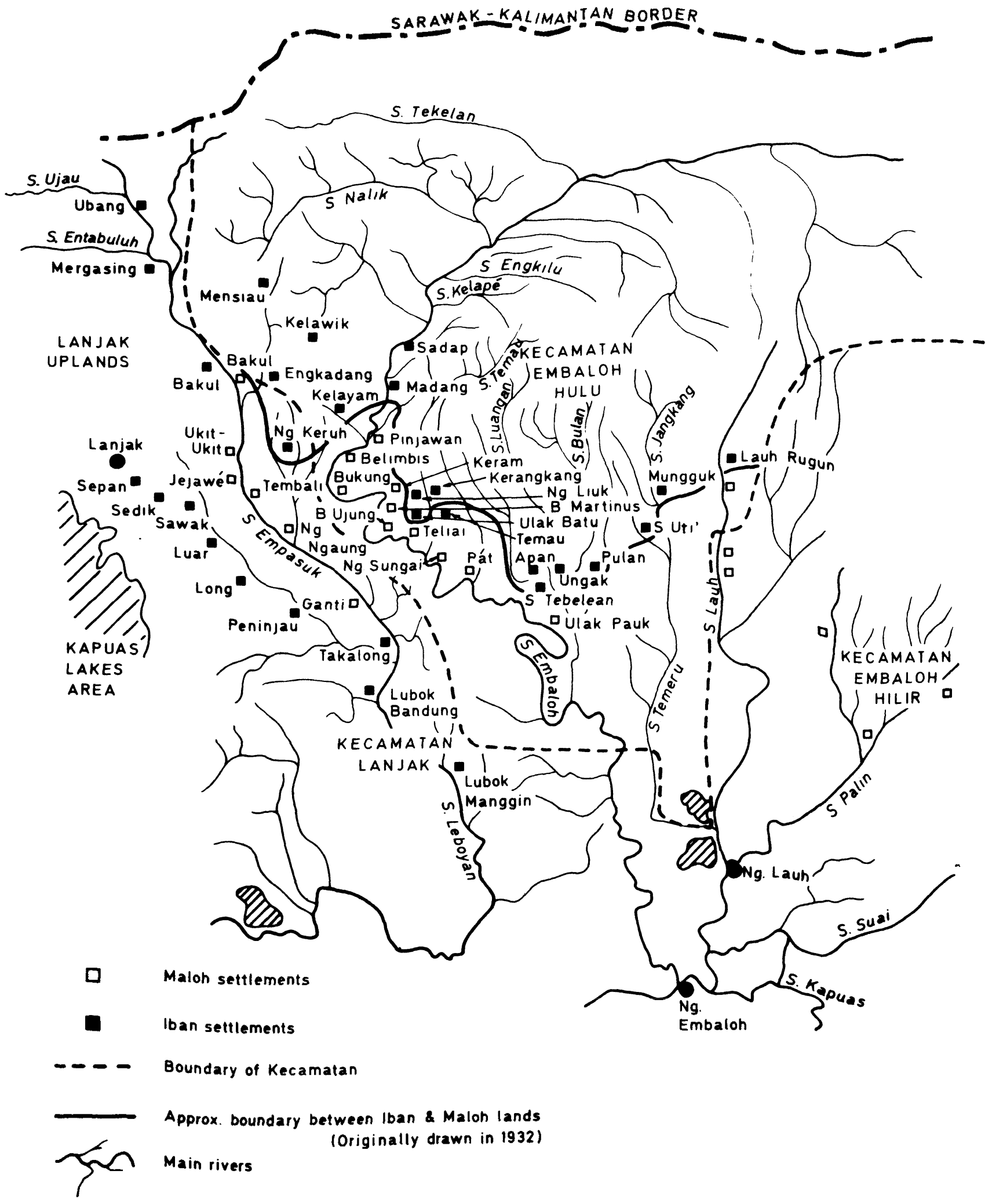


and Ketungau Dayaks a1so suffered Iban aggression. 42

Estimating the size of Iban populations in Dutch Borneo is even more speculative, since one has to rely on the educated guesses of a few Dutch writers, and, besides, the Iban population has always been in a state of flux because of migration into Sarawak. Veth, the Dutch historian of West Borneo, reports that as early as the $1830 \mathrm{~s}$ about four thousand Iban families were living in the lakes area and in the area of the upper Leboyan and Embaloh rivers.43 Allowing about five persons per family as a rough estimate, this gives a total population of about twenty thousand, which seems unduly large. In the 1850s, von Gaffron reported only sixty-eight Iban villages in Dutch territory, consisting of 1,250 families.44 In 1883, Kater gave a figure of about six hundred families inhabiting the regions of Seriang, Tangit, Luwar and Tekenang (see Figure II).45 Ten years later Enthoven estimated that there were approximately seven hundred families, comprising something like 3,500 souls. ${ }^{46}$ There seems then, despite the uncertainty of the statistics, to have been a general fall in numbers in the course of the nineteenth century, due perhaps to the return movement of the Iban into the Rejang basin in Sarawak.

On the other hand the Maloh population on the Embaloh, Leboyan, Lauh and Palin rivers remained remarkably stable. In the mid-nineteenth century, van Lijnden estimated the number of "Maloh Dajaks," excluding the Taman and Kalis subdivisions, at 2,925.47 In the $1890 \mathrm{~s}$ Enthoven put their numbers at 3,920. There is a further figure for the early $1930 \mathrm{~s}$ of 2,648 for the Embaloh subdivision, and 5,687 for the Iban. 48 What the above figures do not reveal adequately is that the Iban population as a whole was increasing. It certainly appears to have declined in Dutch Borneo in the nineteenth century but this area was the source of migrants into Sarawak and there the population was growing at a rapid rate.

In the $1830 \mathrm{~s}$ Iban settlement extended from the Sarawak border areas to Lake Luwar and beyond to the Leboyan and Embaloh. 49 When the Dutch established an outpost at Selimbau on the upper Kapuas in 1856, Iban were said to be located along the rivers to the north of the Kapuas lakes such as the Tangit, Senunuk, and Seriang, along the Embaloh tributaries, and the Empanang to the west of the lakes.50

42. J. E. L. Burgemeestre, "Onze Verhouding tot Sarawak en de Batang Loepar-bevolking" (unpublished, Semitau, 1934), p. 5.

43. P. J. Veth, Borneo's Wester-afdeeling (Zaltbommel: Noman, 1854), p. 55.

44. H.A.A.N., "Batang-Loepars," p. 31 .

45. Kater, "Iets over de Batang Loepar Dajakhs," p. 2. These rivers, which are in the Kapuas lakes area, fall within what the Dutch termed "Batang Lupar country" (Batang-Loeparlanden).

46. Enthoven, Bijdragen tot de Geographie, p. 231.

47. Baron D. W. C. van Lijnden, "Aanteekeningen over de Landen van het Stroomgebied der Kapoeas," Natuurkundig Tijdschrift voor Nederlandsch Indië, II (1851), p. 583 .

48. W. H. E. Scheuer, "Memorie der Afdeeling Sintang" (Mvo, Tropen Instituut, Amsterdam, 1932), Appendix D.

49. Veth, Borneo's Wester-afdeeling, p. 55 .

50. Burgemeestre, "Onze Verhouding," p. 8. 
Freeman, in his Sarawak study, indicates that Iban were already established on tributaries of the Rejang by the $1850 \mathrm{s.51}$ Iban contact with the Maloh must therefore have become more frequent from the $1830 \mathrm{~s}$ on.

Early Iban migration routes and settlements largely avoided the main Maloh concentrations. There were paths crossing the upper Leboyan, penetrating some of its tributaries, and following the upper Embaloh river to the Rejang. A second route further to the north went via the Sumpa, Entabuluh and Ujau rivers into upstream tributaries of the Embaloh. Thus the Iban initially confined themselves to the sidestreams of the Leboyan and Embaloh, mainly upstream from existing settlements.

Obviously some peripheral Maloh villages were affected by Iban movements. The closest settlements to Iban pioneer areas were in the Lanjak region. One such was Pamandian Puné (literally, Punés Bathingplace), upriver of the present trading center of Lanjak. Its inhabitants, harassed by Iban before their great migrations were under way, moved to the Leboyan. Later on Leboyan villages along the Empasuk river, which drains the Lanjak uplands, fought with migrating Iban and eventually moved into the main Leboyan settlement areas.52 Before the mid-nineteenth century there were also a few villages in the upper Embaloh river--Tatangai, Malit, Supapé, and Banyu--which were gradually abandoned. Initially, the Iban had avoided these peripheral longhouses as well, but as they moved into virgin forest near Maloh villages, raids increased. Maloh people felt it unsafe to farm in the area, and so Supapé, Banyu and Tatangai were gradually abandoned by the mid-nineteenth century. Some of the inhabitants moved further downriver to the villages of Belimbis and Pinjawan. Malit was eventually abandoned about sixty to seventy years ago.

This early period from about 1800 to the $1860 \mathrm{~s}$ was marked by Iban migrations to and via the Embaloh and Leboyan river areas. The virgin forests of the Rejang, the upper Embaloh and Leboyan seemed to be their main goal. As pioneers moved into the area they would erect small, temporary farm-huts until resources had been accumulated to build a long-house. In certain cases it was some years before Iban eventually decided to build more permanent houses. Generally they took over virgin forest rather than recently cleared tracts of Maloh 1 and. There was also some intermarriage between Iban and Maloh early on, mainly Maloh girls marrying into Iban houses as a means to cement peaceful relations. Interestingly enough, Maloh also point out that the Iban settled closest to them were not feared as much as those living farther away, since the nearby villages had established relatively peaceful relations. It was the distant Sarawak Iban who engaged more frequently in raiding, not, it seems, to seize territory but to take heads. Some Maloh moved further downstream to consolidate their settlement for defensive purposes. No doubt Iban movement into virgin areas led to some conflict with Maloh already established there, but Maloh also moved because of long-distance Iban raiding from Sarawak.

\section{Dutch Intervention and Pacification}

The Dutch first established contact with Iban in 1855 in the Kapuas lakes area, and, in 1859 and 1864 , faced with Malay rebellions

51. Freeman, Report on the Iban, pp. 132-33.

52. Enthoven, Bijdragen tot de Geographie, p. 231. 
in the regions of Sintang and Melawi, the Dutch used Iban warriors as mercenaries. 53 The Iban showed great enthusiasm for these government expeditions, since it gave them an official means of attacking enemies, taking heads and plundering. On the other side of the border the White Rajahs, Charles and James Brooke, recruited Iban forces for punitive expeditions on a much larger scale. These government actions operated in a traditional context, taking advantage of enmity between Dayak groups, but what differed was the size of the attacking forces. The Europeans introduced their organizational and military skills and their political power into a situation largely characterized by small-scale raiding. In consequence, it seems that the colonial powers exacerbated rather than decreased indigenous hostilities. 54

There was a great deal of intra-Iban conflict as well as Iban attacks on non-Iban peoples. In the early $1870 \mathrm{~s}$ Iban from Sarawak and the Dutch border areas were feuding between themselves, and in 1872 raids from Sarawak penetrated the Sintang region and in 1875 spread to Bunut. 55 In 1876, Iban from the Rejang basin in Sarawak 1 aunched a fierce attack against Maloh people along the Lauh river, to the east of the Embaloh. The survivors moved to the Mandai and Peniung rivers further south. 56 It appears from the literature that the main problems arose from Iban on the Batang Lupar attacking Iban and other peoples in Dutch territory, and recent Iban migrants from the Rejang crossing the watershed to the upper Embaloh and raiding further south. "Rebels" fleeing from Sarawak forces would also take refuge on Dutch soil and incite Dutch (Iban) subjects to launch raids into Sarawak. To combat these activities the Dutch gradually changed their military tactics in the $1870 \mathrm{~s}$. Whereas the Brookes continued to use the punitive expedition to extend their power and silence "rebels," the Dutch began to set up outposts in strategic areas commanded by trained military personne1. For example, after the Iban attacks in 1875 , a military detachment was posted at Bunut, and in 1876 a further fortification was erected at the mouth of the Embaloh river. Nevertheless, the Dutch still used the punitive expedition on a small scale, although indigenous forces were largely replaced by well-armed, regular soldiers. In 1877 , the Assistant Resident of Sintang headed a small military force against Iban "rebels" from Sarawak who were taking refuge on the upper Leboyan river. Houses and fields were laid waste and promises were exacted from various headmen to cease head-hunting. Only those Iban at the mouth of the Entabuluh river resisted, but the Dutch military pushed them into the hills and burned their houses and farms.57

It was Sarawak Iban hostilities against the Ketungau and Kantu peoples on the western edges of the lakes, however, which prompted the Dutch to establish military posts and to institute patrols along the " border. Troops were sent in 1878 and 1879 to protect the Kantu, and a military outpost was established at Nanga Kantu. Another post followed at Nanga Badau and still others at Pulau Majang, Pangkalang Pesaya, Genting Durian and Lanjak. In 1881, under the auspices of the Dutch administration an exodus of Kantu took place from their homeland on

53. H.A.A.N., "Batang-Loepars," pp. 44-47.

54. Wagner, Colonialism and Iban Warfare, pp. 50-76. However, later Iban piracy was also conducted on a larger scale under the leadership of coastal Malays.

55. H.A.A.N., "Batang-Loepars," pp. 48-49.

56. Enthoven, Bijdragen tot de Geographie, p. 67.

57. H.A.A.N., "Batang-Loepars," pp. 49-50. 
the Empanang. They were resettled along the Kapuas river to remove them from the constant attacks of Sarawak Iban. 58

After the Kantu moved, Iban raids tended to concentrate on the Embaloh area. But Iban aggression was reduced by the new presence of the Dutch in the lakes area. In 1882, for example, a large number of Sarawak Iban came into Dutch territory in the hope of enlisting fellow Iban to raid the Maloh on the Leboyan. Fortunately, the controleur at Nanga Badau managed to calm his own Iban, but those from Sarawak were still not satisfied and in August of that year they attacked. But through the good offices of the controleur a settlement was reached between the two parties. In 1883 , there were still sporadic outbreaks of head-hunting and an attempted Iban attack on the Leboyan, but this was diverted by a military patrol from Badau, supported by the government steamer "Singkawang," which was usually'stationed at Semitau.59

As the situation quietened in the lakes area the military post at Badau was wound up in 1887 , and the controleur left in 1889. Eventua1$1 y$ the outpost was abandoned altogether in the $1890 \mathrm{s.60}$ Nevertheless there was still a good deal of tension between the Leboyan people and the Iban of Sarawak. From 1885 onwards, the Dutch government took further steps to protect those Dayak who were exposed to Iban aggression. Some of the Leboyan were encouraged to move further downstream. Many had already done so the previous year because a number of Sarawak Iban, after attacking Ketungau and Iban settlements in Dutch territory, took refuge in the Leboyan river and caused much alarm.61 A fortified longhouse was built at Jejawe south of Ukit-Ukit and garrisoned by Malay soldiers, though they eventually left in 1887. The Dutch also supplied Leboyan people with weapons and ammunition, 62 and in January 1886 the controleur of Badau managed to secure peace between the Iban and Leboyan. 63

In the mid-1880s Charles Brooke was considering a further punitive expedition against the unruly upper Batang Lupar Iban. He had already sent two major expeditions in 1868 and 1875 . The Dutch reluctantly agreed to allow him passage through their border areas, and in March 1886 the rajah undertook the Kedang Expedition which, among other things, resulted in the destruction of some eighty long-houses and Dutch complaints that friendly Iban subjects along the Tangit river had been attacked.64 Whereas the rajah's measures were relatively unsuccessful against Iban head-hunting, Dutch military methods proved quite effective. The Dutch therefore gradually abandoned the punitive expedition which they felt merely served to exacerbate inter-Dayak enmity. 65

58. Burgemeestre, "Onze Verhouding," pp. 9-10.

59. H.A.A.N., "Batang-Loepars," pp. 52-53.

60. Enthoven, Bijdragen tot de Geographie, p. 230.

61. Ibid., p. 58; E. B. Kielstra, "Bijdragen tot de Geschiedenis van Borneo's Westerafdeeling," De Indische Gids, XV/2 (1893), p. 2100.

62. Burgemeestre, "Onze Verhouding," p. 12.

63. Kielstra, "Bijdragen tot de Geschiedenis," p. 2101. 64. Ibid., pp. 2101-2.

65. Pringle, Rajahs and Rebels, pp. 240-42. It should be noted that the Iban problem in Dutch West Borneo was of smaller proportions than in Sarawak. Iban were a minority population in Dutch-controlled areas, and relatively easy river and lake transport to the border regions greatly helped Dutch supervision of their own Iban subjects and Iban movements and raids from Sarawak. 
Eventually, in 1887 , there were peace-making negotiations between the Iban and those Maloh of the Embaloh subdivision held at Lubok Antu. In the following year further peace-making took place between Sarawak Iban, Maloh and Kantu peoples.66 Deshon, the Resident of Sarawak's Second Division commented on these reconciliations as follows:

Although hostilities have ceased since the Kedang expedition, yet they [Iban chiefs] said they are unable to interchange visits or to go to each other's country without restriction until a formal peacemaking has taken place.

I was sometime ago informed by the Controleur at Badau that the Malohs are equally anxious for this arrangement and they have $I$ believe already deposited some jars with him as a pledge of good faith. 67

During the late $1880 \mathrm{~s}$ a number of Iban in the lakes area were also encouraged to move into more accessible locations. Various headmen were chosen by the Dutch to keep order, lay out rice fields and build better and more permanent long-houses.68 The Dutch military measures discussed above and the apparent desire of the Iban for peace led to a period of relative stability from 1888 until the mid-1890s. The Dutch abandoned most of their permanent outposts and relied mainly on patrols to maintain order.

Unfortunately trouble broke out again between the Iban leader Bantin, who lived on the upper Batang Lupar, and the British authorities, and in 1898 a government-initiated expedition set off "against him. He fled across the border, took temporary refuge on Dutch soil and continued to launch attacks against both Sarawak Iban and those in the lakes area, as well as people along the Ketungau.69 In response to these developments, but more particularly because of rumors of another British punitive expedition against the upper Batang Lupar Iban, the Dutch brought in military patrols. In 1902, for example, troops under the command of two controleurs were sent to occupy two strategic points. Controleur Berkholst with eleven soldiers headed for the Embaloh and the Leboyan, while Controleur Tip went to Pulau Majang and the Iban areas of Senunuk and Sumpa. These moves were meant mainly to prevent their Iban subjects joining Bantin's rebels, but also to guard against the Sarawak expedition crossing the border and attacking innocent communities in Dutch territory. ${ }^{\circ}$ In general, Bantin kept on friendly terms with the Dutch. But the rajah sent another expedition against him in 1908, resulting, in 1909, in Bantin's permanent migration with some eighty families to the upper Leboyan.71

A further Dutch measure to pacify the Iban was the introduction of Catholic missionaries into the lakes area. The initial impetus in this region came from the controleur of Semitau who believed that the "civilizing" influence of the missions might accomplish more than the

66. Kielstra, "Bijdragen tot de Geschiedenis," p. 2101.

67. H. F. Deshon, "Simanggang Monthly Report," Sarawak Gazette, XIV (1888), p. 66.

68. Kielstra, "Bijdragen tot de Geschiedenis," p. 2102.

69. Pringle, Rajahs and Rebels, pp. 221-30; Burgemeestre, "Onze Verhouding," pp. $16-17,27-28$.

70. Burgemeestre, "Onze Verhouding," pp. 16-17.

71. Pringle, Rajahs and Rebels, p. 232; Burgemeestre, "Onze Verhouding," pp. 19-20, 28 . 
government in controlling head-hunting. In 1908, therefore, he urged the Dutch Capuchin fathers to consider a center at Lanjak since the military post had been wound up there. ${ }^{2}$ Early attempts at conversion failed, and, in the course of the next thirteen years, continued Iban reluctance to embrace Christianity and send their children to the mission school led to the abandonment of the station.

Meanwhile priests had also visited the Leboyan and Embaloh rivers and came to the conclusion that their best opportunities lay there. Embaloh inhabitants seemed keen to become Christians and send their children to school. Initially some Maloh children had gone to the school in Lanjak but their parents were constantly afraid for their safety since they had to travel through Iban country to get there. In addition, at the Lanjak school there were often conflicts between Iban and Maloh children. The Catholic fathers therefore thought it best to confine the Iban to Lanjak and the Maloh to Martinus. ${ }^{3}$ Pastor Gonzalvus was the first Catholic missionary to visit the Embaloh river in 1911. He noticed that Maloh long-houses were close to the river bank and connected to the river's edge by a raised plankwalk. This, he said, enabled the inhabitants to beat a hasty retreat as soon as news of an Iban attack was received. Villages were located close together, being no more than twenty to thirty minutes walk apart. Some villages comprised more than one long-house clustered together for purposes of security and defense.74 Even though hostilities between Iban and Maloh had considerably diminished since the peacemaking of the late $1880 \mathrm{~s}$, Maloh still feared Iban raids from Sarawak.

For the Maloh people the establishment of a mission station on the Embaloh river had an important influence on future relations with Iban. The Catholics decided to set up their mission at a place they called Benua Martinus, a focal point on the Embaloh river, between the villages of Keram and Benua Ujung. ${ }^{5}$ The Dutch government then set up a post at Benua Ujung with a native officer (assistant demang). From then on the mission and government posts provided a natural focus for Dutch administrative interest. This was perhaps one of the main factors which prevented more extensive Iban encroachment into Maloh territory. Unfortunately there is very little information on events along the Leboyan in the twentieth century, and the remaining historical information is principally taken from the local mission records.

At the turn of the twentieth century Iban migrants began to move into the regions to the east of the Embaloh river. Apart from the Lauh river which had been occupied by Iban in the latter part of the nineteenth century, the regions to the east of the Embaloh had remained virtually unoccupied. In this later period Iban continued to pose cer= tain problems for the Dutch. Bantin, after a relatively peaceful period, began to make trouble again. The British Resident Page-Turner and the Dutch Assistant Resident in Sintang, van der Meulen, met to attempt to work out a solution to the problem. ${ }^{76}$ Controleur Hilbrander

72. Maxandrea, De Dajaks, pp. 176-77. 73. Ibid., p. 177.

74. P. Gonzalvus, "Iets over de Embaloeh-Dajaks," Zondagsblad (van het Kath. Huisgezin, P. P. Capucijnen, 1911), pp. 380-81; Molengraaff, Geologische Verkenningstochten, p. 154 .

75. Golzalvus, "Iets over de Embaloeh-Dajaks," pp. 412-13; A.S., November 20, 1912.

76. Burgeestre, "Onze Verhouding," p. 29. 
of Semitau was sent to the Leboyan area with a troop of soldiers since, at this time, there had been rumors that three Sarawak heads had been taken by Leboyan Iban. Unrest continued and there was a Dutch show of force in early 1917 against Iban on the upper Leboyan and its tributary the Entabuluh. A large number of Iban were moved to the lower Leboyan to the south of the main Maloh settlements. The troops also confiscated Iban weapons and the captured heads were returned. The whole action was carried out very peaceably, and only Bantin resisted. Controleur Hilbrander gave him the choice of either taking an oath of allegiance to the Dutch government or returning to Sarawak. He opted for the former and established himself in the upper Mensiau, where he died in 1932 .

Another trouble spot was the Rejang river. Iban there had frequently embarked on head-hunting raids. For example, between 1868 and 1876 Charles Brooke sent four expeditions against the Katibas Iban and many of these fled into Dutch Borneo. ${ }^{77}$ Much later, in 1915, Sarawak forces raided the Mujong and Gat rivers and the rebels retreated to the upper Gat; in 1919 there was a further expedition to the Gat resulting in a number of Iban seeking refuge in Dutch territory.78 This evoked a response from the Dutch who feared further head-hunting, and they dispatched troops to the Embaloh river in 1918 and 1919 and captured some of the rebels. A number were taken to Semitau and then returned to the Sarawak government. ${ }^{79}$

For the $1920 \mathrm{~s}$ and $1930 \mathrm{~s}$ there are scattered references to sporadic raiding between Iban in Sarawak and those in Dutch territory, but during this period there is no mention of attacks against the Embaloh and Leboyan. Perhaps the presence of the mission and government offices in Martinus and Benua Ujung, which afforded some degree of protection and a means of calling on military aid from outside, discouraged Iban attacks. But there were raids against other peoples. For example, in 1923 the mission records report that a large crowd of Iban from the Leboyan had collected in the marketplace at Benua Ujung. They were spoiling for a fight with the Mentebah people living on the Bunut river further south, since one of their number had been killed there. "They were talking, getting excited and brave and strutting about." 80 Controleur Cator was informed and managed to persuade them to return to the Leboyan.

Furthermore in 1932 there were tense relations between the Iban and their traditional enemies the Kantu. Nine followers of the renowned Sarawak head-hunter Asun were traveling from the Rejang, and stayed overnight at a Kantu house on the upper Suai river, to the east of the Lauh and Palin. While the Kantu were sleeping the Iban took eight heads and severely wounded three people. They managed to escape and fled back to Sarawak with only one casualty. Lieutenant van den Kolk from Putus Sibau visited the Embaloh, Luangan and Suai rivers to avert any further Iban-Kantu conflict, since there was a great commotion among the Kantu, who were bent on revenge.81 Iban who lived near Kantu settlements were also alarmed because they feared reprisals.

\footnotetext{
77. Pringle, Rajahs and Rebe1s, pp. 216, 254.

78. Ibid., p. 262.

79. A.S., June 17, August 2, October 16, 1919.

80. Ibid., September 15, 19, 1923.

81. Burgemeestre, "Onze Verhouding," p. 34; A.S., July 17, 18, 1932.
} 
The Dutch sent a number of border patrols into the area to prevent further trouble and in August of that year five Iban from Lanjak went into Sarawak to seek information about the head-hunters. Apparently on their arrival in the Third Division they met the British Resident at Kapit who informed them that the guilty head-hunters would only be punished on a formal request from the Dutch government. He also added that according to rumors many other Sarawak Iban had wanted to go headhunting but did not because of the intervention of unfavorable dreams and omens. Those who returned with the eight Kantu heads were not received by their home villages, and even Asun, the enemy of the rajah, would not give them hospitality. They therefore disappeared into the jungle with their captured heads. They were apparently Iban from the upper Kanowit river. Three of them were friends of an Iban who had formerly been married to an Embaloh woman in Pinjawan. They must therefore have been well known along the Embaloh river. ${ }^{82}$

More trouble occurred towards the end of 1933 when ten Sarawak Iban arrived in an Iban house on the upper Embaloh looking for a certain Mawang, who had led the small party to the Rejang the previous year in search of the head-hunters.83 The Dutch sent a patrol to the area and all was again quiet. The following year in May, Sergeants Bogert from Putus Sibau and Rietberger from Semitau went to the upper Embaloh in response to rumors that Kantu were planning a raid on Iban houses, while Captain Ling and Controleur Burgemeestre from Semitau caught forty-seven Kantu near an island in the Suai river. 84 They were about to go against the Iban, but the Dutch confiscated their weapons and sent the Kantu to Putus Sibau. 85

During 1934 unrest continued. The Iban in the upper Embaloh were planning a raid across the border. Embaloh people in Temau began to fortify their village and arm themselves. Certain Iban houses upriver began to collect together for defensive purposes.86 The Dutch pastor at Martinus suspected an Iban ruse. Several Iban communities in the Embaloh area apparently wished to move their houses and knowing that the government would not permit it, decided to invent "enemies" as an excuse to move. Burgemeestre went to the upper Embaloh to discover the reasons for the unrest but returned none the wiser. His impression was that there was no basis for Iban anxiety. This all the more convinced the pastor that the commotion was a cunning Iban trick to provide them with an excuse to move, and move some of them did.87

Judan, the Iban leader in the Embaloh region, later met with Embaloh headmen from Ulak Pauk and Pinjawan and told them that he would attempt to force the Iban from the upper Embaloh to move into his area to the east of the Embaloh, since they were continually causing a commotion. To this end the assistant demang, Judan and some Iban headmen went to speak with the Maloh in the Palin about the possibility of Iban moving there. 88 Some of the Iban houses in the upper Embaloh were reluctant to move and the Palin people refused to accept an influx of Iban into their territory. A solution to the problem was reached in 1935 and 1936, when rumors again circulated amongst the Iban in the Embaloh area that there would be raids launched from the upper Batang

82. A.S., August 28, 1932.

84. Ibid., May 12, 1934.

86. Ibid., May 22, 24, 28, 1934 .

88. Ibid., July 2, 1934.
83. Ibid., December 6, 1933.

85. Ibid., May 16, 1934.

87. Ibid., June 10, 1934. 
Lupar. Three Iban houses in the Lanjak area moved to the east of the Embaloh river and Iban from a number of upper Embaloh villages moved in twenty-eight boats to Judan's area. This was accomplished without encroachment on $\mathrm{Pal}$ in 1 and. ${ }^{89}$

Unfortunately during 1936 there was further news of Iban unrest in the upper Embaloh and Assistant Resident Bouman decided that it would be best to move the government outpost from Benua Ujung upstream to Pinjawan to supervise Iban activities. 90 Troops arrived in the Embaloh in response to orders from the Resident in Pontianak, who had himself received a message that thirty-eight head-hunters from Sarawak were taking refuge in Dutch territory. Stories also filtered through that some of the figitives had been receiving food and shelter from the upper Embaloh Iban. Other head-hunters had installed themselves on the Malik river and on the upper Leboyan. A captain and about fifty soldiers from Pontianak, Pinoh, Sintang and Semitau arrived with ninety coolies and thirteen large boats. They were to stay upriver for about three months or until the fugitives had been caught.9l In April the captain had still found nothing. This Dutch vigilance lasted into 1937 when the government outpost was returned to Benua Ujung; but by that time some of the original Sarawak head-hunters who came over in 1935 were still at large. Therefore much of this unrest in the $1920 \mathrm{~s}$ and 1930 s seems to have been the result of Iban head-hunters taking refuge on Dutch soil or indeed raiding Dayak settlements in Dutch territory.

When the Dutch departed in June 1942 they feared that there would be a resurgence of head-hunting. In fact, the Iban seemed to direct much of their aggression against the Japanese invaders, and on the return of the Dutch after the war there were no reports by the Embaloh people of Iban raids against them.

\section{Boundary Settlements}

During the period for which we have relatively detailed records there were two boundary agreements between the Iban and Maloh on the Embaloh river. The first, in 1923, was the culmination of the long period of Iban encroachments discussed earlier. ${ }^{92}$ The agreement related specifically to the Embaloh river. The first meeting, held in Benua Ujung, was led by Temenggung Ma' Lunsa (Ulak Pauk) and Patih Judan (Sungai Uti'), the respective regional heads of the Embaloh and Iban. The list of Embaloh headmen included Ma' Jarup (Pát), Ma' Dingin and Sangkalang (Nanga Sungai), Ma' Terapit and Timbang (Teliai), Ma' Serangan (Benua Ujung), Seluang (Keram), Ma' Rancang (Temau), Ma' Kasso (Bukung), Ma' Balang (Pinjawan) and $\mathrm{Ma}$ 'Sunat (Belimbis). The Iban headmen comprised Langkap, Layang, Tuwa, Mawang, Renang, Bedindang and Bayak from the upper Embaloh. The controleur of the upper Kapuas, W. J. Cator, also attended. At this meeting the Iban formally retained title and rights to the land on the upper Embaloh, and were also allowed to live on its eastern tributaries, mainly in the upper sections of those streams above Embaloh and Kantu farming areas. Most of the areas mentioned were already occupied by scattered Iban settlements. Some of the main rivers allotted to them were the upper Temau, the Uti', Jangkang, and Bulan (see Figure III).

The agreement allowed Iban from regions to the west (Lanjak and the Leboyan) and from Sarawak to settle in this area. But various

89. Ibid., February 7, 1935, June 1936.

91. Ibid., March 18, 1936.
90. Ibid., March 27, 1936.

92. Ibid., May 24, 1923. 


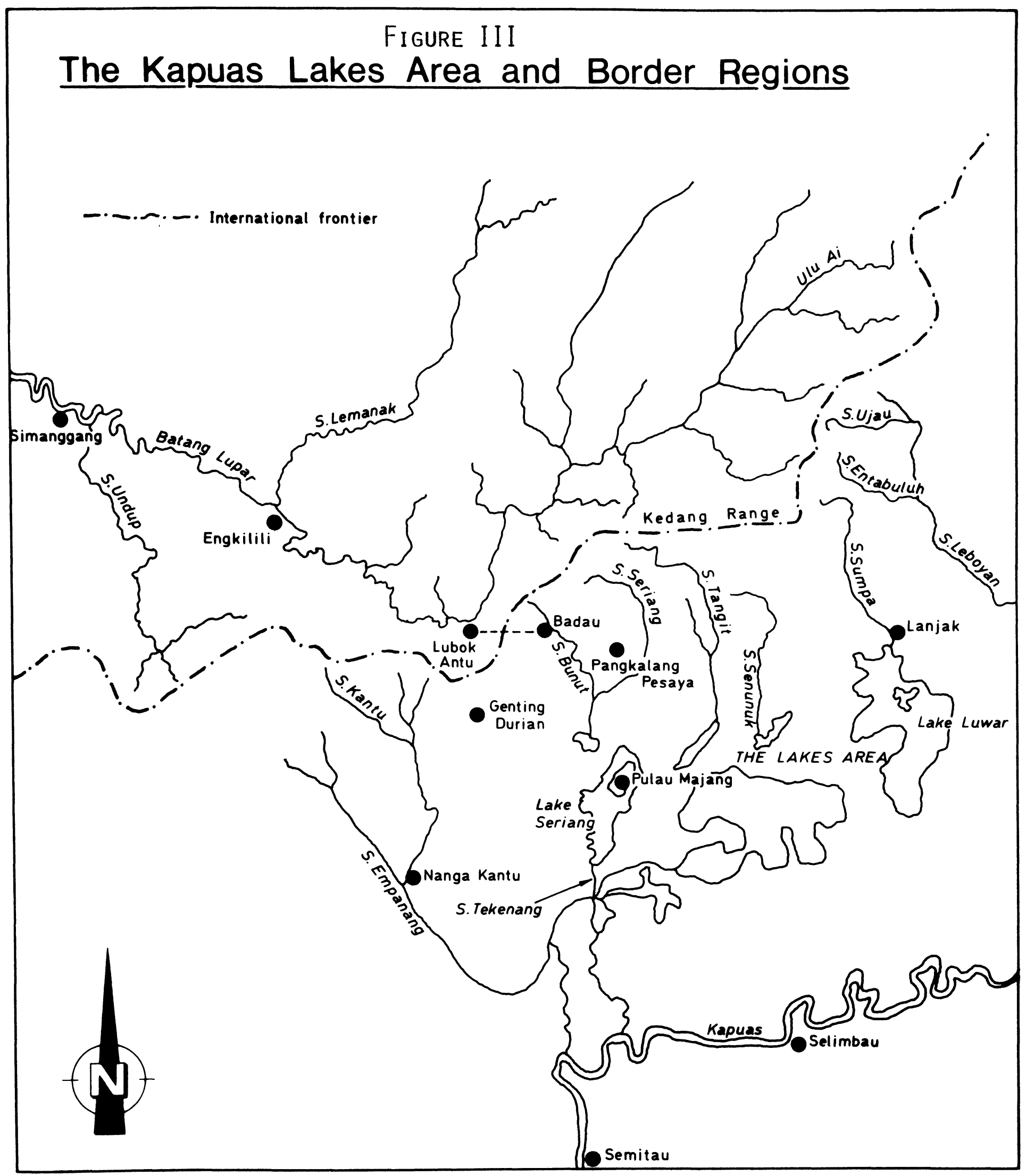


regulations were laid down which are indicative of the kinds of problems which the Iban posed for the Dutch. Iban had to keep themselves to areas indicated by the government. They had to clear a pathway immediately so that their villages were connected with other nearby villages. They were not allowed to open up arbitrarily more forest for farming than was needed in any one year, and in the second year of settlement Iban migrants must build a permanent long-house.

In spite of this agreement, during the next ten years it proved exceedingly difficult to control Iban migration and farming. In 1927 , the pastor at Martinus warned various Embaloh headmen that they must prevent the gradual annexation of their lands. 93 In addition, the Embaloh headman of Ulak Pauk, Rejang, had received ten Iban families into his village. The pastor felt that Rejang had no right to disobey the 1923 regulations and that other headmen should make strong representations to the then Controleur Kelly who had apparently consented to Rejang's actions. In 1930, the pastor asked the controleur about the eight remaining Iban families in Ulak Pauk, urging him to follow the 1923 agreement and force them to move. ${ }^{4}$ An Embaloh delegation went to the government post at Benua Ujung and asked that the Iban be compelled to leave. The controleur and the assistant demang suggested that the Embaloh had no case since their own people had given the Iban permission to settle there. The government had also placed faith in Iban promises that they would adopt Embaloh adat and behave themselves.

The pastor was probably one of the important agents who slowed down Iban penetration. In the interests of his Embaloh people he was constantly bringing their problems to the attention of the authorities. This was made easy for him through the government office and the mission, and the various military patrols which were sent to control Iban unrest. He was above all convinced that Iban agricultural techniques were disastrous for the whole environment and he continually pointed out that Iban occupancy of the areas to the west of the Embaloh river in Lanjak, and the Leboyan, Mensiau and Kelayam rivers, their cultivation of steep slopes and their practice of overfarming had destroyed large areas of forest and made it virtually useless for future cultivation. Since by 1931 , the pastor still had received no satisfactory response from the assistant demang and the controleur, in August of that year he took the matter to the Assistant Resident in Sintang. 95

The problem came to a head when Iban from areas to the east of the Embaloh became involved in a land dispute with some villagers in Ulak Pauk. It also became apparent to the government that far from Iban becoming absorbed into Embaloh society they were so numerous that they threatened to overrun areas of Embaloh land. Largely through the efforts of the pastor, another meeting to decide boundaries was therefore arranged and in 1932 a second agreement reached.96 The negotiations were presided over by the controleur of the upper Kapuas, van den Kolk. A list of those Iban headmen present indicates that this time there was a substantial interest from Iban to the east of the Embaloh river in such villages as Sungai Uti'.

The boundary between Iban and Embaloh was redrawn. It cut across the Kelayam river to the northwest and north of the northernmost Embaloh settlements of Pinjawan and Belimbis, continuing to the east of

93. Ibid., July 9, 1927.

95. Ibid., August 25, 1931.
94. Ibid., January 15, 1930.

96. Ibid., April 21, 1932. 
the Embaloh river and cutting through the Temau, Luangan, Bulan and Temeru rivers (see Figure III). By this agreement the Iban long-house of Talas above Pinjawan was given eight months to move to the Engkilu river in the upper Embaloh area. All its fruit and rubber trees and other enterprises had to be transferred to the Embaloh people after the 1933 rice harvest. The village of Ungak also had to move by 1934 , as did two other Iban houses. It was finally decided that the Iban families resident in Ulak Pauk had to move within eight months to Iban territory, and after the rice harvest of 1932 any Iban farming within Embaloh boundaries would be fined by the government.

Later the pastor wrote a letter to the controleur explaining that the Embaloh were worried about the boundary decisions which had been reached in Apri1.97 Some of the Iban were very angry and felt that they had been ill-treated, but they took no subsequent action. Between 1933 and 1935 there were sporadic disputes between the two peoples over 1and. Captain Ling, during a visit to Benua Ujung, suggested that a neutral zone be established between the Embaloh and Iban, and this intermediate area be settled by Malays. The pastor was very much against this, as were the Embaloh, since it was their general opinion that Malays were never neutral. In the past, the Embaloh had themselves been victims of Malay land-grabbing attempts.98

In mid-1936, the Iban in the Ulak Pauk area were again making their farms on Embaloh land. Lieutenant van Wijk from Sintang, along with the assistant demang and the leader of the Embaloh went to investigate and found that the headman of U1ak Pauk, Rejang, had again given them permission to farm. The decision was that they had to move out the following year. ${ }^{99}$ In 1940 further disputes were recorded.

There is very little information on record about the Leboyan river, but from the present day situation Leboyan people seem to have suffered more from Iban encroachment than their Embaloh cousins. This is not surprising since the Leboyan is much closer to the main areas of Iban settlement in the Kapuas lakes area and the Dutch were not on the spot, as they were on the Embaloh river. Consequently there were no boundary regulations. By the $1870 \mathrm{~s}$ Iban houses were well-estab1 ished in the upper Leboyan area, particularly on the tributaries of the Entabuluh and Ujau, and lower down on the Empasuk and Ngaung. Until about 1910, Iban generally confined themselves to the upper Leboyan. It was in 1917, after the troubles with Bantin and the Iban on the Entabuluh that the Dutch decided to move a number of them to more accessible regions of the lower Leboyan. This unfortunately meant that Leboyan people were now encircled by Iban settlement. Since that time the Leboyan population has concentrated itself in the remain ing Leboyan villages. The continued movement of Iban into and out of the area and the fact that overall the Iban were more numerous than the Leboyan has also meant a greater degree of Iban assimilation of Leboyan over the last hundred years.

This long period of Iban movement via the border regions of Dutch West Borneo illustrates a number of important features of Iban expansion and warfare, in the context of their contact with Maloh. First, Iban were more interested in acquiring and opening up virgin forest areas than seizing tracts of already farmed land in the possession of

97. Ibid., August 15, 1932.

98. Ibid., April 1935.

99. Ibid., August 1936. 
other peoples. For this reason they could move into largely unoccupied regions. Their movement did, however, bring them into contact with forest nomads, and indeed with such settled peoples as the Maloh to the east of the Kapuas lakes, and there was some conflict over rights to virgin land. Maloh settiement also contracted somewhat. A second point to note is that Iban migration and contact with others was not marked by aggression in a11 instances. They had peaceful trading relationships with Maloh based on the exchange of certain craft products. Iban occupation of virgin land left unexploited by Maloh also meant that conflict was minimized, and peaceful relations were established between nearby Iban and Maloh villages expressed in terms of intermarriage and trade. Third, although there was local conflict over virgin land in particular, raiding was carried out mainly by more distant Iban in Sarawak. This perhaps suggests that other motives are also operative in Iban warfare. Apart from the desire for virgin land, Iban also required heads which played an important role in Iban notions of prestige, health and fertility. A fourth point is that intra-Iban warfare was just as important, if not more important, than aggression directed against outsiders. Finally, there is the factor of colonial intervention, which increasingly affected the direction and intensity of Iban migration and warfare in the course of the nineteenth century. Headhunting was ultimately curbed. The Dutch gave protection to various of the border Dayak, including the Kantu, Maloh and their own Iban subjects. They moved large numbers of Kantu further south away from the danger of Iban attack. They introduced military patrols and outposts to guard the border against attacks from Sarawak, and indeed to prevent their own Iban participating in head-hunting. They resettled Iban to provide them with farming lands, prevent them from head-hunting and remove them from Sarawak Iban influence and aggression. They provided the Maloh with military protection and controlled, to a certain extent Iban encroachment into Maloh land.

It is difficult to suggest what the outcome would have been had the Dutch not intervened. Nevertheless, it would seem that in the Maloh area, while virgin land was available for the Iban and while Maloh alluvial land could support them, some kind of balance would have been established. Increasing intermarriage and ties of friendship with associated trade and other economic relations might also have resulted in the gradual absorption of Maloh by the more numerous Iban. Yet the Dutch did halt the Iban advance and it remains now to look briefly at the present day situation.

Iban and Maloh Today

Iban settlement is still spread out in the Kapuas lakes region and eastwards to the Embaloh and beyond. Based solely on the Indonesian census for 1971 and random figures collected by myself and Dutch Catholic missionaries, I estimate that there are approximately seven thousand people in West Kalimantan who recognize themselves as Iban.100 This excludes such people as the Kantu, Bugau, and Mualang. The population for the Embaloh subdivision is approximately 4,320 .

After independence and the removal of the Dutch, and in the disruption caused by the Japanese interregnum, Iban encroachment into

100. Hasil Sensus Penduduk 1971 (Propinsi Kalimantan Barat: Kantor Sensus dan Statistik, 1971); P. Schwerz, untitled and unpublished ms., Benua Martinus. 
Maloh land continued apace. Today there appear to be no very strong governmental controls on this process, nor on Iban farming practices. On the Leboyan river Iban encirclement of Maloh settlement is complete. To the north are the Iban houses of Ubang and Mergasing. To the west is the Empasuk river, running along the Lanjak foothills almost parallel to the main Leboyan river and here the Iban houses of Sawak, Luar, Long and Peninjau are found. To the south are Takalong, Lubok Bandung and Lubok Manggin; to the east Nanga Keruh, Mensiau, Kelawik and Engkadang (see Figure III). Takalong was originally a Maloh settled area, but is now almost completely occupied by Iban, and there has been a good deal of intermarriage with the Maloh inhabitants of Bakul, Ganti and Nanga $\mathrm{Ng}$ aung.

In the upper Embaloh river area there are now only two Iban longhouses, Madang and Sadap. During Confrontation, Iban further upriver from these two settlements were ordered by the Indonesian military to move further downstream. At that time, in the ear1y 1960s, there were still a number of Iban villages above Madang and Sadap, in the region of the Engkilu and Kelape rivers. A number of the inhabitants moved into Sarawak to settle with relatives there; some joined the present house of Madang; still others traveled to the east of the Embaloh river and settled in the Temeru-Uti' area. In the last ten years there has also been an Iban movement into the heart of Embaloh territory. Iban from the Kelayam area to the west of the Embaloh river asked Embaloh leaders if they could move into an area below the Embaloh village of Benua Ujung because of lack of suitable land for farming and the insecurity caused by Confrontation. The opinion of various Embaloh leaders differed considerably on this point, but eventually the Iban were allowed to move into virgin territory and establish a house at Ulak Batu. There were various conditions laid down--they were supposed to send their children to the local Catholic school; they had to keep their pigs penned and they could not trespass on Embaloh 1 and. Initially three families migrated there, but since then the numbers have risen to eleven. This increase has caused a great deal of dispute between Ulak Batu and the nearby villages of Teliai and Nanga Sungai over 1 and and fruit trees. Disputes between Iban and Embaloh over resources are fairly commonplace especially now with the increase of population numbers on both sides. In the months of December and January 1972-73 there were quarrels between the Embaloh villages of Belimbis, Pinjawan, and Bukung and the nearby Iban settlements on the Kelayam river.101

As a result of these disputes and past uneasy relations between Iban and Embaloh there is still some mutual suspicion, despite crosscutting ties of kinship and friendship. Related to this is the problem of schooling. Iban are still very reluctant to send their children to school. First, because Iban settlements tend to be at greater distances from the Catholic school and, in any case, Iban parents are still not convinced of the school's value; second, there are often troubles between Iban and Embaloh children. They frequently fight between themselves, and conflicts between Iban and Embaloh adults, particularly over land and fruit trees, are sometimes carried over into the classroom. In the $1950 \mathrm{~s}$ a dispute of this kind resulted in Embaloh keeping their children away from school to prevent them mixing with Iban.

101. V. T. King, "Embalohs and Iban in Kalimantan," Sarawak Gazette, IC (1973), pp. 36-37. 
On the other hand there are various friendly relations between Iban and Maloh expressed in terms of trade. In the past Maloh would normally travel to Iban houses to manufacture metal adornments in exchange for Iban woven goods. While this Maloh craft has declined in importance in recent years, it has been replaced in this upper Kapuas region by Iban demand for Maloh rice. This, of course, was always a trade item, but according to various reports Iban have become increasingly dependent on rice from the Leboyan and Embaloh rivers. In particular, Iban bring such things as baskets to trade, particularly the tall type used for carrying rice from the fields (Emb: dédétan; Iban: lanyi) and the smaller variety used during the actual harvesting of rice $(b a k u l)$. Other Iban trade items are forest raw materials such as rattan and pandanus, the latter being used in the manufacture of hats (saraung). Aside from actual trade, Iban may also beg food from Maloh acquaintances or kinsmen. Less skillful Iban agricultural practices on infertile hill slopes mean that Iban are often faced with food shortages. Maloh informants told me that Iban sometimes have to eat their rice as soon as it is harvested since they have no extra supplies from previous years. In the village which I visited in February 1973 Iban were harvesting and already consuming newly cut $r i c e$, and before the harvest some were eating cassava. A number were also coming into Maloh villages asking for food, but more particularly many were trading their heirlooms, such as woven skirts, in return for rice. Still others were selling their mats and baskets to the local Catholic mission for money with which to buy rice.102 This problem of Iban rice shortages and bad harvests is certainly not a new phenomenon and was already frequently reported in mission records of the $1930 \mathrm{~s}$.

A further interactional element is in the sphere of work relationships. To obtain much-needed rice Iban often work on Maloh farms, particularly for those people who are close relations or friends. Those villages closest to Iban settlements such as Belimbis, Pinjawan and Temau tend to recruit the most Iban. For the Iban this is an important means of obtaining rice, and for the Maloh it provides an opportunity to ease the burden of such activities as weeding and harvesting and allows them to carry on with other work.

Intermarriage is also increasing between Iban and Maloh. In the past, when hostilities were more prevalent, marriage tended to be much more a means of achieving peace and cementing alliances, and contracts were sometimes entered into between Iban leaders and Maloh samagat. As peaceful conditions obtained and Iban settled closer to Maloh villages there was a greater amount of sexual relations and marriage at ali levels of society. At the present time Iban and Maloh are becoming increasingly interrelated through kinship, while close proximity of settlement, trade, economic cooperation, and visiting are cementing various social ties. Meaningful statistics on marriage between the two peoples are difficult to obtain but the following may be of some help. Out of a random sample of ninety-six Maloh households on the Embaloh river, which comprised a total of one hundred and seventy marriages, eighteen individuals were married to Iban (about ten percent of the marriages). Of these, five men had married into Iban villages in the area, and one was living in his natal village with his Iban wife. Twelve Maloh women were married to Iban, four of whom were resident in their own villages, while the other eight had followed their

102. For a general description of present day Iban villages in the upper Embaloh area see V. T. King, "Ethnographic Data on the Iban of the Embaloh Region, West Kalimantan," Sarawak Gazette (1975), forthcoming. 
husbands. It would seem that the incidence of intermarriage is somewhat higher on the Leboyan river. In certain Embaloh villages such as Ulak Pauk, Pát and Keram there were Iban families actually resident. These had, through various ties, been allowed by the local Maloh headmen to settle and open virgin forest within the respective village territories.

These closer relations have also resulted in a degree of cultural exchange. It is difficult to determine with any certainty what is original to the two cultures and what has recently been taken from others, but it would seem that the Maloh on the Embaloh and Leboyan rivers have incorporated a number of Iban words into their language. This is mainly because most Maloh are fairly fluent in Iban. Sometimes when I asked them to give me a term for a jungle plant or tree, or a cultural object, they would give me the Iban term. Only after close questioning would it be revealed that the Embaloh had their own word. Iban basket designs are also copied by Maloh. Maloh had their own methods and styles of basket manufacture, but through trade they also acquired Iban items and frequently copied them.

Similarities in religious beliefs are very difficult to attribute to cultural exchange, but both Iban and Maloh are not averse to seeking out each other's curing specialists for advice. In one case Maloh villagers went some distance to procure the services of a skilled Iban medical expert when their own cures failed to work. Maloh curing stones were also sometimes obtained from Iban sources.

A final problem which is difficult to answer is the reason for the success of Iban encroachment and assimilation of other ethnic groups in Borneo. In the case of the Embaloh subdivision, the large numbers of Iban moving into the area probably made it very difficult for the Maloh to absorb them. The process has more often than not worked in favor of the Iban. Iban hold more tenaciously to their traditional customs, whereas various historical circumstances have led the Maloh to abandon many of theirs. It also seems that more Maloh villagers have intermarried into Iban houses, although the reasons for this are by no means clear. As Wagner points out, broadly similar cultural and socio-economic features throughout Borneo present very few problems of adaptation to an inmarrying individual. The greater number of Iban moving into and through Maloh areas in the last one hundred and fifty years or so, has probabiy been a major factor in the Maloh's limited but gradual absorption. The process has also been aided by the ease with which Maloh become fluent in the Iban language and the reluctance and difficulty of Iban in mastering the Maloh tongue.

A real problem which faces the Embaloh area today is its increasing inability to feed its population. Iban frequently face food shortages and a considerable area has been rendered unsuitable for future farming because of prodigal agricultural practices. At the moment, Maloh are managing to produce surpluses in most years, but some of this is being drained off to feed Iban. Moreover, Maloh 1 and is becoming restricted because of Iban and Kantu encirclement, and there is greater pressure on resources because of an increase in the Maloh population in recent years. Already in some parts of the Embaloh region the fallow period between farming cycles has shortened to four or five years. There is a possibility that soil exhaustion will result in falling yields in the Embaloh as wel1. One improvement has been the adoption of high-yielding wet rice seeds by certain Maloh villages, but these are not utilized to their full extent because of difficulties in providing suitable drainage and irrigation, and further the lack of fertilizers. Increasing pressure on the land could therefore lead to serious conflicts in the future. 